\title{
Poly I:C induces collective migration of HaCaT keratinocytes via IL-8
}

\author{
Kazuhide Takada ${ }^{*}$, Shihoko Komine-Aizawa ${ }^{1 *}$, Naoko Hirohata ${ }^{1,2}$, Quang Duy Trinh ${ }^{1}$, Atsuyoshi Nishina ${ }^{3}$, \\ Hirokazu Kimura ${ }^{4}$ and Satoshi Hayakawa ${ }^{1}$
}

\begin{abstract}
Background: Delayed wound healing reduces the quality of life (QOL) of patients. Thus, understanding the mechanism of wound healing is indispensable for better management. However, the role of innate immunity in wound healing is thus far unknown. Recently the involvement of TLR3 in wound healing has been evaluated. The systemic administration of polyriboinosinic-polyribocytidylic acid (poly I:C ; a substitute for viral dsRNA and a ligand of toll-like receptor 3), enhances wound healing in vivo. The aim of this study is to improve our understanding of the link between innate immunity and human wound healing, particularly in re-epithelialization.

Results: The present study showed that poly I:C significantly accelerated collective HaCaT cell migration in a scratch assay. Poly I:C also increased IL-8 and bFGF production, and anti-IL-8 antibodies significantly inhibited the migration caused by poly I:C. Human recombinant IL-8 also accelerated collective HaCaT cell migration. An immunofluorescence assay and enzyme-linked immunosorbent assay (ELISA) also revealed that poly I:C decreased E-cadherin protein levels and increased vimentin protein levels, and anti-IL-8 antibody reversed this effect. In contrast, nucleic/cytosolic protein ratios of Snail 1 were unchanged in all tested conditions.
\end{abstract}

Conclusion: Our findings demonstrated that poly I:C accelerated collective HaCaT cell migration via autocrine/ paracrine secretions of IL-8 and the subsequent incomplete epithelial-mesenchymal transition (EMT). Our findings provide a new strategy for wound healing by regulating innate immune systems in re-epithelialization.

Keywords: Collective migration, Epithelial-mesenchymal transition, IL-8, Keratinocyte, Poly I:C, Toll-like receptor, Wound healing

\section{Background}

The skin is the frontline of innate immunity and works as a physical and chemical barrier. Thus, skin injury enables the entry of pathological microorganisms and disrupts homeostatic function. Though a skin wound is usually repaired rapidly, wound healing is delayed in the elderly and/or in patients with diabetes mellitus. Delayed wound healing increases the risk of morbidity in diabetic foot ulcers [1] and pressure ulcers [2]. Thus, understanding the mechanism underlying wound healing is needed to develop better treatments. Recently, accumulating data have indicated important roles of innate immunity in wound healing [3]. Stakeholders in innate immunity

\footnotetext{
* Correspondence: takada-smr@umin.ac.jp; aizawa.shihoko@nihon-u.ac.jp ${ }^{1}$ Division of Microbiology, Department of Pathology and Microbiology, Nihon University School of Medicine, 30-1 Oyaguchi Kami-cho, Itabashi-ku, Tokyo 173-8610, Japan

Full list of author information is available at the end of the article
}

include toll-like receptors (TLRs), which recognize pathogen-associated molecular patterns (PAMPs) from invading pathogens and damage-associated molecular patterns (DAMPs) released from injured tissues and cells [4]. Therefore, the recognition of PAMPs or DAMPs via TLRs triggers an inflammatory response in both sterile and nonsterile conditions during wound healing [5].

TLRs have negative and positive roles in wound healing. In diabetic foot ulcers, the recognition of DAMPs by TLRs has been proposed to lead to an excessive and prolonged inflammatory response, resulting in impaired wound healing [6]. However, the beneficial effects of TLRs in wound healing have also been reported. For example, TLR4 plays an essential role in early skin wound healing [7]. HMGB1, an endogenous ligand of TLR4, accelerates wound healing $[8,9]$, whereas a bacterial lipopolysaccharide, an exogenous ligand of TLR4, delayed cutaneous wound healing [10]. Activation of 
TLR9 by CpG oligodeoxynucleotides accelerates wound healing [11]. Deficiency in Nod2, a cytoplasmic recognition receptor for multiple host patterns, also results in delayed wound healing [12]. In addition to studies on TLR4 and TLR9, the involvement of TLR3 in wound healing has been recently evaluated. The systemic administration of polyriboinosinic-polyribocytidylic acid (poly I:C), a ligand of TLR3, enhances wound healing in vivo [13]. In recent studies, skin wound repair was significantly delayed in TLR3 null mice [14], and poly I:C promoted wound repair of human and murine skin [15]. Increases in the expression of genes involved in skin barrier formation, lipid accumulation, and epidermal organelles were observed with poly I:C stimulation [16]. Interestingly, TLR3 signaling is involved in hair neogenesis after wound formation [17]. Thus, it is important to understand the correlation between wound healing and the skin virome or DAMPs, which could in turn lead to better treatments. However, the roles of viral flora in non-pathological conditions and the involvement of innate immunity remain unclear. Here we investigated the effects of poly I:C on the collective migration of an immortalized human keratinocyte cell line ( $\mathrm{HaCaT}$ cells). The migration and proliferation of keratinocytes were observed beginning in the intermediate phase of inflammation [18]. This process, known as epithelialization, is a crucial component of wound repair, sealing the epidermal defect and re-establishing barrier function $[19,20]$. The aim of this study was to improve our understanding of the link between innate immunity and human wound healing, particularly in reepithelialization.

\section{Methods}

\section{Cell culture}

$\mathrm{HaCaT}$ cells were kindly provided by Dr. N.E. Fusenig (German Cancer Research Center, Heidelberg, Germany) and grown in Dulbecco's Modified Eagles Medium (DMEM) (Gibco, Carlsbad, CA, USA) containing 10\% fetal bovine serum, $100 \mathrm{U} / \mathrm{ml}$ penicillin and $100 \mathrm{U} / \mathrm{ml}$ streptomycin at $37{ }^{\circ} \mathrm{C}$ in $5 \%$ humidified $\mathrm{CO}_{2}$.

\section{Scratch assay}

$\mathrm{HaCaT}$ cells were grown to confluence on 24-well microplates (Iwaki Glass, Chiba, Japan). A linear scratch was made using a $2 \mathrm{~mm}$-wide Cell Scratcher ${ }^{\mathrm{mm}}$ (Iwaki Glass), and the wells were washed once with phosphate buffered saline (PBS). Immediately after washing, 0.01, 0.1 , or $1 \mu \mathrm{g} / \mathrm{ml}$ poly I:C (Sigma, St. Louis, MO, USA) was added to the cultures. To inhibit poly I:C stimulation, $30 \mu \mathrm{g} / \mathrm{ml}$ chloroquine diphosphate (Wako Pure Chemical Industries, Osaka, Japan), dissolved in the same culture medium, was added. Cells were then fixed and stained with $7.5 \%$ formaldehyde and $0.25 \%$ crystal violet (Wako Pure Chemical Industries) at $0,24,48$, or $72 \mathrm{~h}$ after the scratch. Grid seals (Iwaki Glass) were affixed onto the bottoms of the wells, and images of the remaining wound area in a $3 \times 8 \mathrm{~mm}^{2}$ rectangle, at the center of the well (approximately one-half of the scratch wound), were obtained under a stereoscopic microscope and measured using Image J software (NIH). To inhibit proliferation, cells were treated with $10 \mu \mathrm{g} / \mathrm{ml}$ of mitomycin C (Kyowa Hakko Kirin Co, Tokyo, Japan) for $2 \mathrm{~h}$ and then washed with PBS once immediately before the scratch was made. To prevent the confounding effect of IL-8, anti-IL-8 antibody (1:200; IBL, Gunma, Japan) was added to the medium immediately after the scratch. Human recombinant IL-8 (50 or $500 \mathrm{ng} / \mathrm{ml}$; Sigma) was also added just after the scratch to confirm the effects of IL-8.

\section{Cell viability assay}

HaCaT cells were seeded (5000 cells per well) onto a 96well microplate (Iwaki Glass, Chiba, Japan) 24 h before poly I:C, and chloroquine were added at the same concentrations as described above. Next, the cells were incubated for 24,48 , or $72 \mathrm{~h}$, and cell viability was measured using a Cell Counting Kit-8 (Dojindo Laboratories, Kumamoto, Japan) according to the manufacturer's instructions. The cell density in each well was measured at $450 \mathrm{~nm}$ using a microplate reader (iMark Microplate Absorbance Reader, Bio-Rad, Hercules, CA, USA).

\section{Enzyme-linked immunosorbent assay (ELISA) of IL-8, transforming growth factor (TGF)- $\beta 1$, E-cadherin, vimentin, Snail, and basic fibroblast growth factor (bFGF)}

The IL- 8 , TGF- $\beta 1$ and bFGF concentrations in culture medium were measured using an ELISA kit (R\&D Systems, Minneapolis, MN, USA) according to the manufacturer's instructions. The culture supernatants with or without poly I:C and anti-IL-8 antibody at the same doses as described above were collected at $24 \mathrm{~h}$ after the scratch and centrifuged at $3000 \mathrm{rpm}$ for $15 \mathrm{~min}$. Cellfree supernatants were then harvested and stored at $-20{ }^{\circ} \mathrm{C}$ (for IL-8) or $-80{ }^{\circ} \mathrm{C}$ (for TGF- $\beta 1$ and bFGF) until further assay. The concentrations in each well were measured at $450 \mathrm{~nm}$ using a microplate reader (Bio-Rad). We also measured the protein levels using an ELISA kit of E-cadherin (R\&D Systems), Vimentin (Cell Signaling Technology, Danvers, MA, USA) and Snail (Cloud-Clone Corp, Houston, TX, USA) according to the manufacturer's instructions. Whole cell lysates were extracted using cell lysis buffer (Cell Signaling Technology) or nucleic/ cytosolic fractions were extracted using cell fractionation kit-standard (Abcam) according to the manufacturer's instructions and stored at $-20{ }^{\circ} \mathrm{C}$ prior to use. Protein concentrations were determined using the RC DC protein assay kit (Bio-Rad). 


\section{Immunofluorescence assay}

$\mathrm{HaCaT}$ cells were grown to confluence on 24-well microplates (Iwaki) and scratched with or without the combination of $0.1 \mu \mathrm{g} / \mathrm{ml}$ poly I:C and anti-IL-8 antibody (1:200) as described above. Cells were fixed with $4 \%$ paraformaldehyde $24 \mathrm{~h}$ after the scratch. Cells were washed with $1 \%$ bovine serum albumin (BSA, Sigma) in PBS and incubated with 3\% BSA for $30 \mathrm{~min}$. Next, the cells were incubated with anti-IL-8 antibody (1:50; IBL), anti-TGF- $\beta 1$ antibody (1:100; Cell Signaling Technology), anti-E-cadherin antibody (1:100; Abcam, Cambridge, UK), anti-vimentin antibody (1:150; Abcam), and anti-Snail 1 antibody (1:150; Abcam) for two hours at room temperature. Then, the cells were washed and incubated with the secondary antibody, CF488A-labeled anti-rabbit antibody (Biotium, Hayward, CA, USA), for $30 \mathrm{~min}$ at room temperature. For negative controls, the primary antibody was replaced with $1 \%$ BSA in PBS. Samples were counterstained with 4',6-Diamidino-2Phenylindole, Dihydrochloride (Biotium) for nuclear staining. To maintain cytokines in the cells, brefeldin A (50 $\mathrm{\mu g} / \mathrm{ml}$; Sigma) was added to the culture medium $4.5 \mathrm{~h}$ before fixation (only for IL-8 and TGF- $\beta 1$ staining).

\section{Bright field imaging of the scratched edge margin}

$\mathrm{HaCaT}$ cells were grown to confluence on 24-well microplates (Iwaki) and scratched with or without $0.1 \mu \mathrm{g} / \mathrm{ml}$ poly I:C. After $24 \mathrm{~h}$ of incubation, bright field images were obtained using EVOS FLoid Cell Imaging Station (Thermo Fisher Scientific, Boston, Massachusetts, USA).

\section{Statistical analysis}

Statistical comparisons were performed using the TukeyKramer test or Mann-Whitney test. Data are presented as the mean \pm SEM. A probability value of $<0.05$ was considered to represent a significant difference.

\section{Results}

Effects of poly I:C on the collective migration of HaCaT cells

$\mathrm{HaCaT}$ cells were exposed to $0.01,0.1$, or $1 \mu \mathrm{g} / \mathrm{ml}$ of poly I:C and subjected to a scratch assay (Fig. 1a, b). Poly I:C significantly decreased the remaining wound area in a dose-dependent manner, which was reversed by chloroquine, a poly I:C inhibitor, at 24,48 , and $72 \mathrm{~h}$ after the scratch. Chloroquine alone did not affect the migration (data not shown). However, the remaining wound area was greater at the dose of $1 \mu \mathrm{g} / \mathrm{ml}$ of poly $\mathrm{I}: \mathrm{C}$, than at $0.1 \mu \mathrm{g} / \mathrm{ml}$. Next, we examined the effect of poly I:C on cell viability using a cell counting assay (Fig. 2a). At the doses of 0.01 and $0.1 \mu \mathrm{g} / \mathrm{ml}$, there were no decreases in cell viability. However, $1 \mu \mathrm{g} / \mathrm{ml}$ of poly
I:C decreased the viability, which was significant for 24 and $72 \mathrm{~h}$ incubation treatments. The combination of poly I:C $(0.1 \mu \mathrm{g} / \mathrm{ml})$ and chloroquine did not have a significant effect. We also examined the effect of poly I:C on collective migration (Fig. 2b). Cell proliferation was inhibited by pretreatment with mitomycin $C(10 \mu \mathrm{g} / \mathrm{ml})$ for $2 \mathrm{~h}$ immediately before scratching, and the remaining wound area was significantly decreased with $0.1 \mu \mathrm{g} / \mathrm{ml}$ of poly I:C $72 \mathrm{~h}$ after scratching.

\section{Involvement of IL-8 in poly I:C-mediated effects}

Some cytokines, such as IL- 8 and TGF- $\beta 1$, are known to induce keratinocyte migration. Poly I:C induced the production of IL-8 from HaCaT cells within 6 and $24 \mathrm{~h}$ of incubation after the scratch (Fig. 3a). We also examined the protein levels of TGF- $\beta 1$. However, poly I:C did not have a significant effect in this condition (Fig. 3b). Immunofluorescence assays of IL- 8 and TGF- $\beta 1$ were performed to evaluate the localization of cytokine production (Fig. 3c). Poly I:C increased the immunoreactivity of IL- 8 in a diffuse pattern at $24 \mathrm{~h}$ after the scratch. Immunoreactivity of TGF- $\beta 1$ was also diffuse and not obviously different between control and poly I:C-treated cells. These results were consistent with the ELISA results. Next, we examined whether IL-8 was involved in the poly I:C-mediated effects. Remaining wound areas at $72 \mathrm{~h}$ after scratching were evaluated with or without anti-IL-8 antibody (Fig. 3d). Anti-IL-8 antibody alone did not affect the remaining area compared with the control, while the antibody significantly inhibited the effect of poly I:C. Human recombinant IL-8 also increased the migration in a dosedependent manner (Fig. 3e).

\section{ELISA and immunofluorescence assays of epithelial- mesenchymal transition (EMT)-related proteins}

Next, we examined the potential of EMT using ELISA and an immunofluorescence assay at $24 \mathrm{~h}$ after the scratch. The protein levels of E-cadherin were significantly decreased only in the poly I:C-treated group (Fig. 4a), and the levels of vimentin were increased in the same group (Fig. 4b). In contrast, the protein levels of Snail 1 in both the nucleus and cytosol were unchanged, and the nucleus/cytosol protein ratios were also unchanged (Fig. 4c). Next, immunofluorescence assays were performed to detect the distributions of these proteins (Fig. 4d). In control cells, positive staining of E-cadherin, an epithelial cell marker, was observed in a pericellular pattern, while the immunoreactivity of vimentin, a mesenchymal cell marker, was weakly detected. The immunoreactivity of Snail was detected mainly in the cytosol and weakly in the nucleus. In contrast, in poly I:C $(0.1 \mu \mathrm{g} / \mathrm{ml})$-treated cells, E-cadherin immunoreactivity was decreased, and the pericellular pattern was diminished, while the immunoreactivity of 


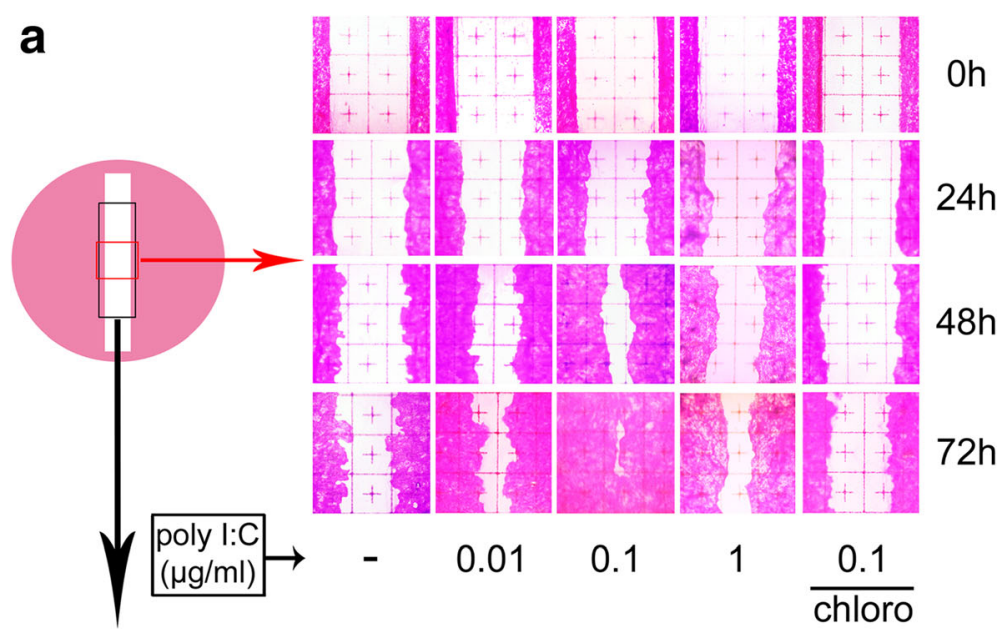

b

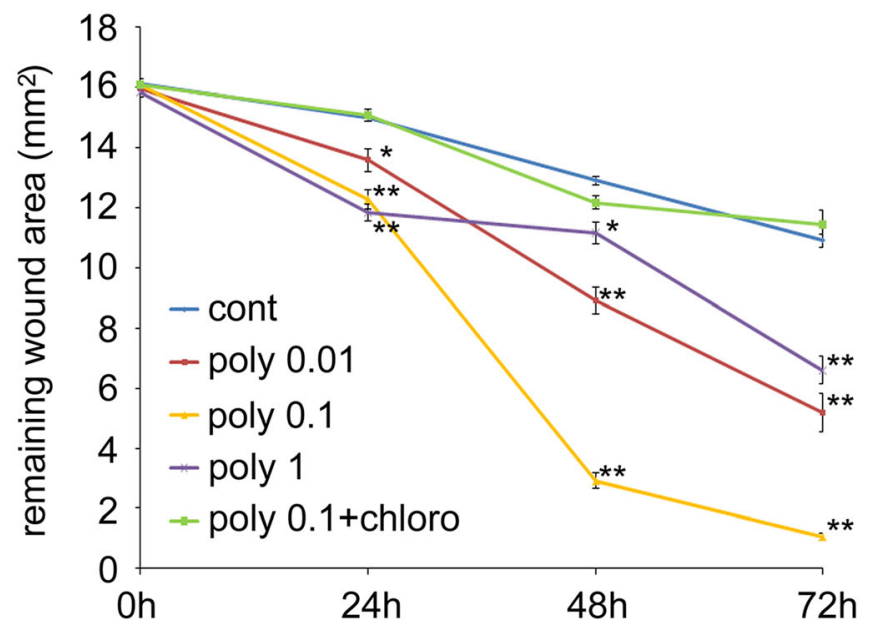

Fig. 1 The effects of poly l:C on the scratch assay with HaCaT cells. a Representative photographs showing the HaCaT cell remaining wound area at 24,48 , and $72 \mathrm{~h}$ after the scratch. $\mathbf{b}$ The remaining wound area in a $3 \times 8 \mathrm{~mm}^{2}$ rectangle $(n=3)$. Data are presented as the mean \pm SEM. ${ }^{*} p<0.05$ vs. control, ${ }^{* *} p<0.01$ vs. control according to the Tukey-Kramer test. Grids $=1 \times 1 \mathrm{~mm}^{2}$. Chloro; Chloroquine

vimentin was increased specifically at the scratched edge. The reactivity of Snail was similar to that of the control. These alterations were not observed in the presence of anti-IL-8 antibody.

\section{Category of collective migration}

The effect of the mitomycin $C$ treatment on migration (Fig. 2b) indicated that the effect of poly I:C did not depend on cell proliferation. Thus, we examined collective migration. Bright field images in both control and poly I:C-treated samples showed a "sheet migration"-like phenomena (Fig. 5a), and the protein levels of bFGF, a stimulant of sheet migration, were significantly increased by poly I:C $(0.1 \mu \mathrm{g} / \mathrm{ml})$ stimulation in culture medium after $24 \mathrm{~h}$ of incubation. This effect was not reversed by the anti-IL-8 antibody (Fig. 5b).

\section{Discussion}

Various mechanisms are involved in the TLR3-related wound healing process. In TLR3 null mice, insufficient recruitment of neutrophils and macrophages was observed, and the expression of chemokines was also decreased in wounds [14]. In addition, poly I:C enhanced the accumulation of leukocytes and upregulated chemokine expression in wound healing [15]. TLR3 was also required for skin barrier repair [21]. To investigate the effects of poly I:C in wound healing, we focused on keratinocytes. We demonstrated that poly I:C accelerated the migration of $\mathrm{HaCaT}$ cells. Moreover, poly I:C induced IL- 8 without affecting TGF- $\beta 1$ secretion. Anti-IL- 8 antibody inhibited the effect of poly I:C, and the antibody also inhibited poly I:C-evoked EMT-related cellular marker alterations. Poly I:C also increased the secretion of bFGF. Taken together, these results suggested that IL- 

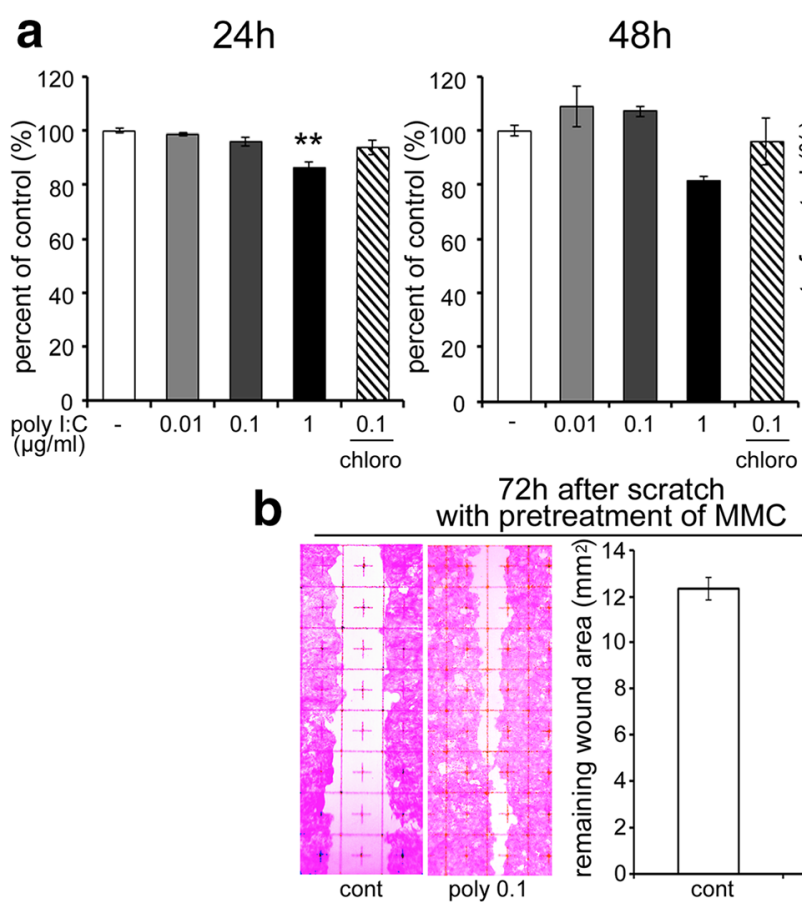

after scratch

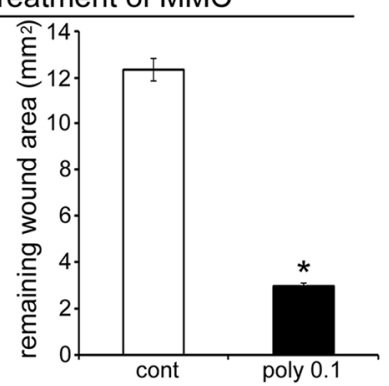

Fig. 2 The effects of poly I:C on HaCaT cell viability and collective migration. a Cell viability measured by formazan formation at 24, 48, and $72 \mathrm{~h}$ after the administration of poly l:C $(n=5)$. $\mathbf{b}$ Representative images showing collective HaCaT cell migration at $72 \mathrm{~h}$ after the scratch with mitomycin $\mathrm{C}$ pretreatment for $2 \mathrm{~h}$, and remaining wound area in a $3 \times 8 \mathrm{~mm}^{2}$ rectangle $(n=3)$. Data are presented as the mean \pm SEM. Grids $=1 \times 1 \mathrm{~mm}{ }^{2}$. ${ }^{*} p<0.05$ vs. control according to the Mann-Whitney test. ${ }^{* *} p<0.01$ vs. control according to the Tukey-Kramer test. poly; poly I:C, Chloro; chloroquine. MMC; mitomycin C

8 produced by keratinocytes via TLR3 stimulation affects wound healing.

Interestingly, poly I:C appears to have opposing actions in wound healing. Although 0.01 and $0.1 \mu \mathrm{g} / \mathrm{ml}$ of poly I:C did not have cytotoxic effects, keratinocyte death is reportedly caused by excessive poly I:C stimulation [22]. Indeed, our present study revealed that at a higher dose of poly I:C, $1 \mu \mathrm{g} / \mathrm{ml}$, cell viability was decreased, and the remaining wound area was greater than that at $0.1 \mu \mathrm{g} / \mathrm{ml}$, although it was still smaller than that observed in the control. Taken together, these data suggest that excessive poly I:C stimulation may delay wound healing.

The potential sources of TLR3 ligands in wound healing should also be discussed. Poly I:C is a ligand of TLR3 and a substitute for both PAMPs of the doublestranded (ds) RNA virus and endogenously generated DAMPs [23, 24]. Although, to the best of our knowledge, there is no evidence supporting the existence of a skin biome of dsRNA viruses, DNA viruses were identified in the skin of healthy humans [25]. It is well known that TLR3 can recognize RNA from any microorganism or dying cell, as mRNA [26] and noncoding RNA [27] are recognized by TLR3. Functional TLR3 is expressed in keratinocytes [28]. Via TLR3 signaling, NF- $\kappa B$ is activated [29], while NF- $\kappa B$ inhibition delays wound healing
[30]. Taken together, these studies suggest the important roles of TLR3 in regulating inflammation as a component of wound healing. Although potential sources of the TLR3 ligand in skin wound healing are still unknown, our present observation suggests that TLR3 plays a physiological role in skin wound healing via accelerated keratinocyte migration. Moreover, commensal bacteria appear to play a regulatory role in reducing the TLR3-dependent inflammatory response after skin injury [31]. Thus, the interactions between the skin microbiota, including bacterial and viral residents as well as DAMPs, remain to be elucidated.

After stimulation of TLRs, many types of cytokines are induced and play differential roles in wound healing. The role of IL-8 in wound healing appears to be complicated. In vivo, topical IL-8 administration significantly diminishes wound constriction [32], whereas, in humans, the level of IL-8 from an unhealed wound biopsy is significantly higher than that of normal skin [33]. The most abundant cytokines in wound fluid reported in surgical drains are IL-6 and IL-8 [34]. This finding might be the result of excessive inflammation caused by IL-8mediated neutrophil recruitment [35] or it may be a representation of keratinocyte death, as poly I:C-induced cytotoxicity and IL-8 secretion have a parallel dose dependence [36]. In the present study, increased secretion 


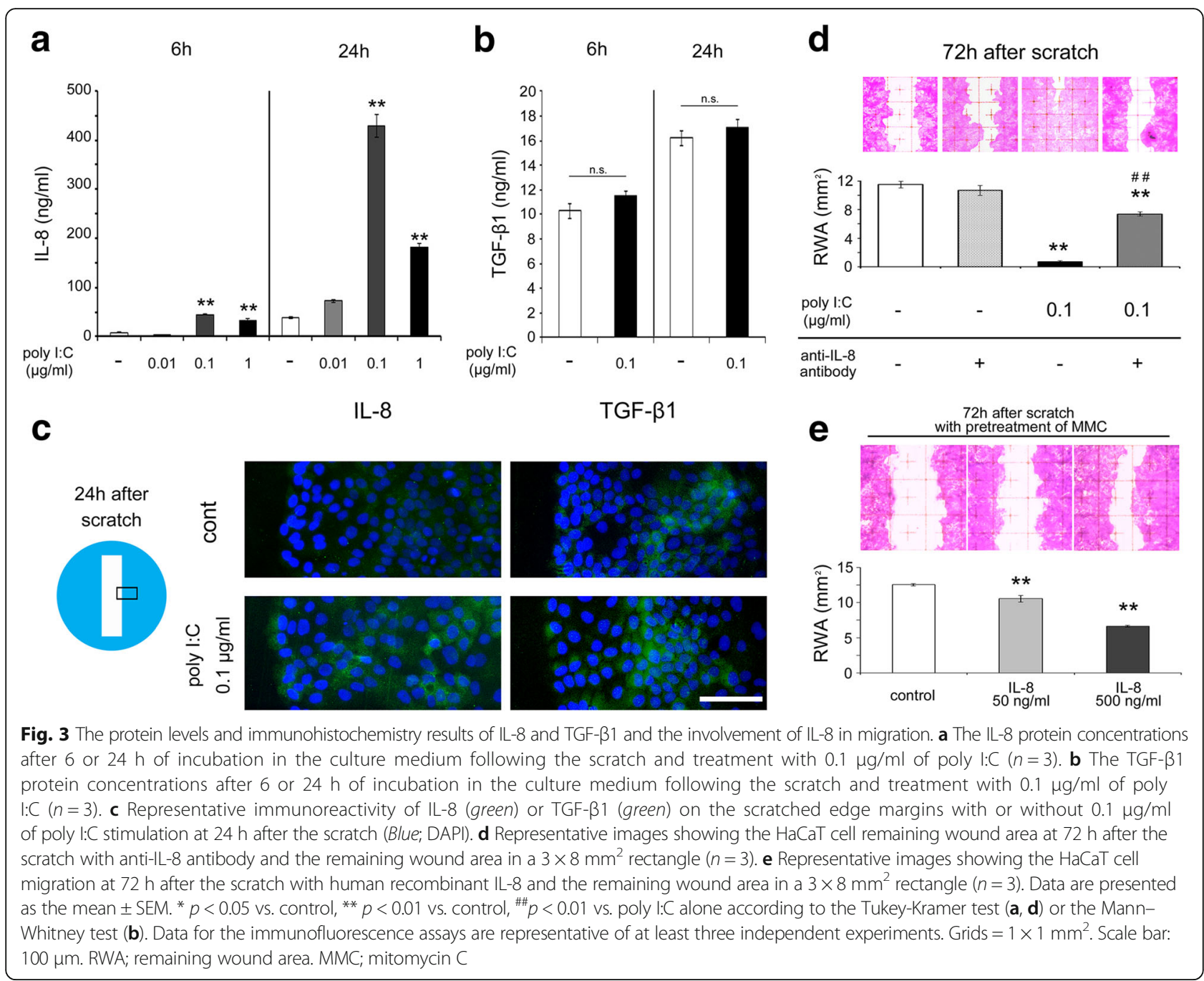

of IL- 8 by poly I:C was detected by ELISA and recombinant IL-8 increased collective cell migration. These observations were consistent with those of previous studies reporting that poly I:C induces $\mathrm{IL}-8$ in $\mathrm{HaCaT}$ and human epidermal keratinocytes $[37,38]$ and that IL-8 increases $\mathrm{HaCaT}$ cell migration $[39,40]$. In null CXCR2 mice, which lack a functional IL-8 receptor, wound healing is delayed [41, 42], and in human skin, topical administration of IL- 8 increased the length of the reepithelialized area [32]. These data indicated the advantageous nature of IL-8 in re-epithelialization during wound healing and show that poly I:C may enhance the autocrine positive-feedback loop of chemokines in epithelialization [43]. In this study, positive correlations were observed between the concentration of IL- 8 at the dose of 0.1 and $1 \mu \mathrm{g} / \mathrm{ml}$ and the results of scratch assays. However, at the dose of $0.01 \mu \mathrm{g} / \mathrm{ml}$, the concentration was not significantly increased, although the remaining wound area was significantly smaller than that of control at $24 \mathrm{~h}$ after scratching. Taken together, these results suggest that IL- 8 was expended in the culture medium by autocrines. Next, we demonstrated that anti-IL-8 antibody showed a limited inhibitory effect (approximately $70 \%$ of the control), suggesting that other mechanisms (i.e., cytokines) are involved in poly I:C-induced collective migration. Further studies to identify other factors that induce the migration caused by poly I:C are needed. In addition, all results presented here were obtained from in vitro studies. Although the scratch assay is a simple, versatile, and cost-effective method, it has some limitations [44]. Thus, more complex methods, such as $3 \mathrm{D}$ cell culture systems and in vivo studies, are required to confirm our results.

Unlike the results obtained for IL- 8 , an increase in TGF- $\beta 1$ was not observed in the present study. TGF- $\beta 1$ promotes keratinocyte migration [45], and systemic administration of poly I:C increases the mRNA levels of TGF- $\beta 1$ in excised wounds [46]. At the protein level, 


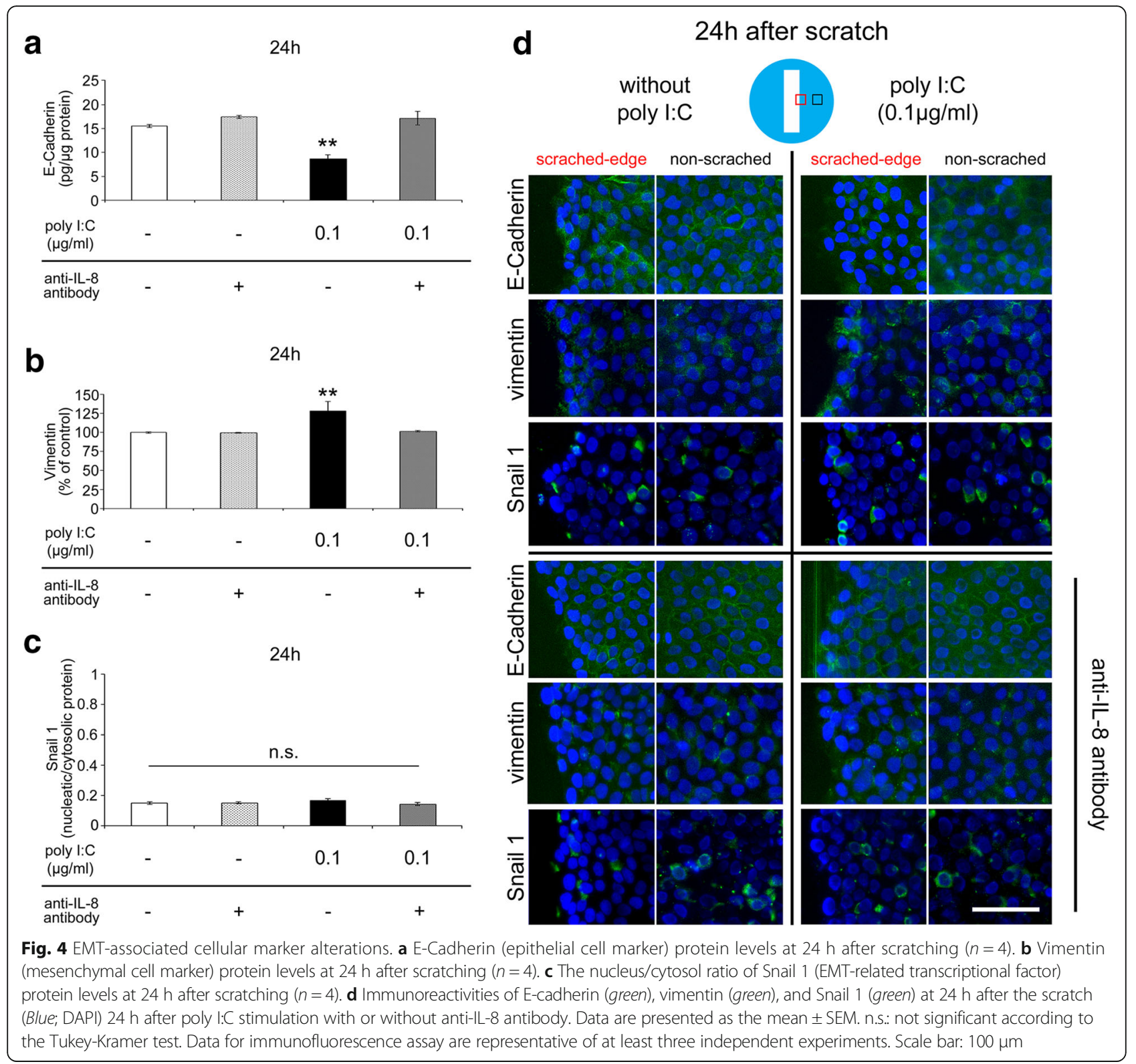

TGF- $\beta 1$ production in poly I:C-stimulated human aortic valve interstitial cells increases in a dose-dependent manner [47]. These data suggest that TGF- $\beta 1$ may be produced in greater quantities by cells other than keratinocytes as a part of wound healing [48]. The interactions between TGF- $\beta 1$ and innate immunity may be important during wound healing.

In addition to the cytokines, cumulative studies have shown the importance of EMT in cell migration. In EMT, cells lose "cell-to-cell" adhesion, have reduced basal cell polarity, acquire a fibroblastic phenotype, and have increased cell motility to migrate or metastasize [49], although EMT can be reversible and is often an incomplete process [50]. In human biliary epithelial cells, poly I:C induces EMT, while the expression levels of TGF- $\beta 1$ and vimentin are not affected [51]. In the present study, the TGF- $\beta 1$ concentration was not affected by poly I:C alone; however, the immunoreactivity of vimentin was increased. This inconsistency may have been caused by the difference in cell types.

Recent studies have also shown that collective migration is sometimes not accompanied by complete EMT but rather by incomplete EMT, although complete EMT generally causes single cell migration [52]. In this study, approximately half the amount of E-cadherin protein was still observed, and we did not observe significant translocation of Snail 1 from the cytoplasm to the nucleus $24 \mathrm{~h}$ after poly I:C stimulation. The unaltered state 


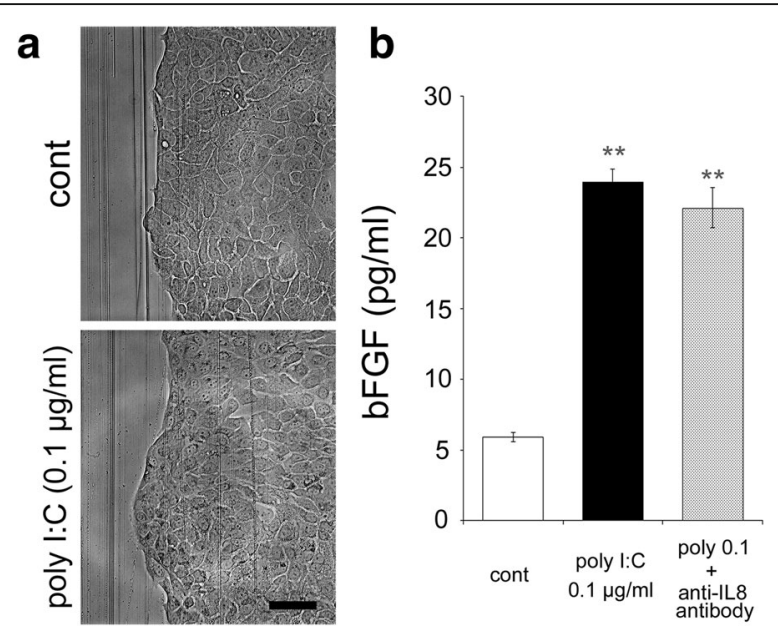

Fig. 5 Bright field image of migration and protein levels of bFGF. a Representative bright field images on the scratched edge margins with or without $0.1 \mathrm{\mu g} / \mathrm{ml}$ of poly I:C stimulation at $24 \mathrm{~h}$ after the scratch. b The bFGF protein concentrations after $24 \mathrm{~h}$ of incubation in the culture medium following the scratch and treatment with $0.1 \mu \mathrm{g} / \mathrm{ml}$ of poly I:C with or without anti-IL-8 antibody $(n=3)$. Data of bright field images are representative of at least three independent experiments. Data are presented as the mean \pm SEM. ${ }^{* *} p<0.01$ vs. control according to the Tukey-Kramer test. Scale bar: $100 \mu \mathrm{m}$

of Snail 1 may be explained by the present observation that an increase in TGF- $\beta 1$ was not observed because TGF- $\beta$ induces the expression of Snail 1 [49]. These findings indicate that incomplete EMT may be induced by a variety of RNAs during wound healing.

Thus far, little is known regarding the identity of the factor that determines complete or incomplete EMT [53]. In the present study, anti-IL-8 antibody inhibited EMT-related cellular marker alterations, indicating that IL-8 may be involved in this process. In tumor cells, IL8 also induces EMT [54]. Tumor collapse could result in the release of RNA, which may evoke EMT via TLR3, resulting in greater invasion or metastasis by the selfsecretion of IL-8 from the tumor. In breast cancer, tumors with a high expression of TLR3 were associated with a significantly greater probability of metastasis [55]. In other hands, with the lack of constitutive activation of RAS signaling pathways, TGF- $\beta 1$ induced an incomplete and transient mesenchymal conversion [56]. Epithelial growth factor (EGF) also induced incomplete EMT in squamous cell carcinoma [57]. Further studies regarding the roles of cytokine and innate immunity in the completeness of EMT in wound healing are needed.

We finally examined the categories of collective migration. According to the results of the bright field images, less sprouting, branching, and slug-like behavior were observed [50]. In addition, bFGF, an important stimulant of sheet migration [58], was significantly increased. These data suggests that the collective migration induced by poly
I:C may be bFGF- mediated sheet migration. However, the bFGF production was not inhibited by the anti-IL-8 antibody, indicating the independence of IL- 8 in bFGF secretion.

\section{Conclusions}

In conclusion, our findings demonstrated that poly I:C accelerated collective $\mathrm{HaCaT}$ cell migration via autocrine/ paracrine secretions of IL-8 and subsequent incomplete EMT. The present study helps improve our understanding of the important role of innate immunity in human wound healing.

\section{Abbreviations}

bFGF: Basic fibroblast growth factor; DAMPs: Damage-associated molecular patterns; EMT: Epithelial-mesenchymal transition; IL: Interleukin:

PAMPs: Pathogen-associated molecular patterns; poly I:C: Polyriboinosinicpolyribocytidylic acid; TGF: Transforming growth factor; TLRs: Toll-like receptors

\section{Acknowledgments}

We thank Mr. Ryo Yamaguchi, 5th year at Nihon University School of Medicine, for his technical assistance. We also thank American Journal Experts for their editorial assistance.

\section{Funding}

This study was supported by a Grant-in-Aid for Scientific Research (B) from the Ministry of Education, Culture, Sports, Science and Technology, Japan with contract grant number 24390382 (to SH) and a grant obtained from the Japan Agency for Medical Research and Development with contact grant number 15ck0106178h0001 (to SH). The funders had no role in the design of the study, the collection, analysis and interpretation of data, and in writing the manuscript.

\section{Availability of data and materials}

The data and data analysis that support the findings of the current study are available from the corresponding authors on reasonable request.

\section{Authors' contributions}

$\mathrm{KT}$, SKA, and SH conceptualized and designed the experiments. KT, SKA, NH, and QDT performed the experiments. AN, HK, and SH helped perform the analysis and contributed conceptually through constructive discussions and critical reading. All authors read and approved the final manuscript.

\section{Competing interests}

The authors declare that they have no competing interests.

\section{Consent for publication}

Not applicable.

\section{Ethics approval and consent to participate} Not applicable.

\section{Publisher's Note}

Springer Nature remains neutral with regard to jurisdictional claims in published maps and institutional affiliations.

\section{Author details}

${ }^{1}$ Division of Microbiology, Department of Pathology and Microbiology, Nihon University School of Medicine, 30-1 Oyaguchi Kami-cho, Itabashi-ku, Tokyo 173-8610, Japan. ${ }^{2}$ Division of Oral Surgery, Department of

Otolaryngology-Head and Neck Surgery, Nihon University School of Medicine, 30-1 Oyaguchi Kami-cho, Itabashi-ku, Tokyo 173-8610, Japan. ${ }^{3}$ Department of Materials and Applied Chemistry, College of Science and Technology, Nihon University, 1-8-14, Kanda surugadai, Chiyoda-ku, Tokyo 101-8308, Japan. ${ }^{4}$ Infectious Disease Surveillance Center, National Institute of Infectious Diseases, Musashimurayama-shi, Tokyo 208-0011, Japan. 


\section{Received: 10 January 2017 Accepted: 13 April 2017}

\section{Published online: 24 April 2017}

\section{References}

1. Rodgers KE, Bolton LL, Verco S, DiZerega GS. NorLeu-Angiotensin (1-7) [DSC127] as a Therapy for the Healing of Diabetic Foot Ulcers. Adv Wound Care (New Rochelle). 2015:4:339-45.

2. Bennett G, Dealey C, Posnett J. The cost of pressure ulcers in the UK. Age Ageing. 2004:33:230-5.

3. Dasu MR, Isseroff RR. Toll-like receptors in wound healing: location, accessibility, and timing. J Invest Dermatol. 2012;132:1955-58.

4. Piccinini AM, Midwood KS. DAMPening inflammation by modulating TLR signalling. Mediators of inflammation. 2010;2010:672395.

5. Kluwe J, Mencin A, Schwabe RF. Toll-like receptors, wound healing, and carcinogenesis. J Mol Med (Berl). 2009:87:125-38.

6. Portou MJ, Baker D, Abraham D, Tsui J. The innate immune system, toll-like receptors and dermal wound healing: A review. Vascul Pharmacol. 2015;71:31-6.

7. Chen L, Guo S, Ranzer MJ, DiPietro LA. Toll-like receptor 4 has an essential role in early skin wound healing. J Invest Dermatol. 2013;133:258-67.

8. Ranzato E, Patrone M, Pedrazzi M, Burlando B. HMGb1 promotes scratch wound closure of HaCaT keratinocytes via ERK1/2 activation. Mol Cell Biochem. 2009:332:199-205.

9. Straino S, Di Carlo A, Mangoni A, De Mori R, Guerra L, Maurelli R, et al. Highmobility group box 1 protein in human and murine skin: involvement in wound healing. J Invest Dermatol. 2008;128:1545-53.

10. Crompton R, Williams H, Ansell D, Campbell L, Holden K, Cruickshank S, et al. Oestrogen promotes healing in a bacterial LPS model of delayed cutaneous wound repair. Lab Invest. 2016;96:439-49.

11. Sato T, Yamamoto M, Shimosato T, Klinman DM. Accelerated wound healing mediated by activation of Toll-like receptor 9 . Wound Repair Regen. 2010:18:586-93.

12. Campbell L, Williams H, Crompton RA, Cruickshank SM, Hardman MJ. Nod2 deficiency impairs inflammatory and epithelial aspects of the cutaneous wound-healing response. J Pathol. 2013;229:121-31.

13. Bhartiya D, Sklarsh JW, Maheshwari RK. Enhanced wound healing in animal models by interferon and an interferon inducer. J Cell Physiol. 1992;150: 312-19.

14. Lin Q, Fang D, Fang J, Ren X, Yang X, Wen F, et al. Impaired wound healing with defective expression of chemokines and recruitment of myeloid cells in TLR3-deficient mice. J Immunol. 2011;186:3710-7.

15. Lin Q, Wang L, Lin Y, Liu X, Ren X, Wen S, et al. Toll-like receptor 3 ligand polyinosinic:polycytidylic acid promotes wound healing in human and murine skin. J Invest Dermatol. 2012;132:2085-92.

16. Borkowski AW, Park K, Uchida Y, Gallo RL. Activation of TLR3 in keratinocytes increases expression of genes involved in formation of the epidermis, lipid accumulation, and epidermal organelles. J Invest Dermatol. 2013;133:2031-40.

17. Nelson AM, Reddy SK, Ratliff TS, Hossain MZ, Katseff AS, Zhu AS, et al. dsRNA Released by Tissue Damage Activates TLR3 to Drive Skin Regeneration. Cell Stem Cell. 2015;17:139-51.

18. Gurtner GC, Werner S, Barrandon Y, Longaker MT. Wound repair and regeneration. Nature. 2008;453:314-21.

19. Coulombe PA. Wound epithelialization: accelerating the pace of discovery J Invest Dermatol. 2003:121:219-30.

20. Pastar I, Stojadinovic O, Yin NC, Ramirez H, Nusbaum AG, Sawaya A, et al. Epithelialization in Wound Healing: A Comprehensive Review. Adv Wound Care (New Rochelle). 2014;3:445-64

21. Borkowski AW, Kuo IH, Bernard JJ, Yoshida T, Williams MR, Hung NJ, et al. Toll-like receptor 3 activation is required for normal skin barrier repair following UV damage. J Invest Dermatol. 2015:135:569-78.

22. Grimstad O, Husebye H, Espevik T. TLR3 mediates release of IL-1 beta and cell death in keratinocytes in a caspase-4 dependent manner. J Dermatol Sci. 2013;72:45-53.

23. Cavassani KA, Ishii M, Wen H, Schaller MA, Lincoln PM, Lukacs NW, et al. TLR3 is an endogenous sensor of tissue necrosis during acute inflammatory events. J Exp Med. 2008;205:2609-21.

24. Yang Z, Stratton C, Francis PJ, Kleinman ME, Tan PL, Gibbs D, et al. Toll-like receptor 3 and geographic atrophy in age-related macular degeneration. $\mathrm{N}$ Engl J Med. 2008:359:1456-63.

25. Foulongne V, Sauvage V, Hebert C, Dereure O, Cheval J, Gouilh MA, et al. Human skin microbiota: high diversity of DNA viruses identified on the human skin by high throughput sequencing. PLoS One. 2012;7:e38499.
26. Kariko K, Ni H, Capodici J, Lamphier M, Weissman D. mRNA is an endogenous ligand for Toll-like receptor 3. J Biol Chem. 2004;279:12542-50.

27. Bernard JJ, Cowing-Zitron C, Nakatsuji T, Muehleisen B, Muto J, Borkowski AW, Martinez L, Greidinger EL, Yu BD, Gallo RL. Ultraviolet radiation damages self noncoding RNA and is detected by TLR3. Nat Med. 2012;18:1286-90.

28. Voss A, Bode G, Kerkhoff C. Double-stranded RNA induces IL-8 and MCP-1 gene expression via TLR3 in HaCaT-keratinocytes. Inflamm Allergy Drug Targets. 2012;11:397-405.

29. Kawai T, Akira S. Toll-like receptor downstream signaling. Arthritis Res Ther. 2005;7:12-9.

30. Lee DJ, Du F, Chen SW, Nakasaki M, Rana I, Shih VF, et al. Regulation and Function of the Caspase-1 in an Inflammatory Microenvironment. J Invest Dermatol. 2015:135:2012-20.

31. Lai Y, Di Nardo A, Nakatsuji T, Leichtle A, Yang Y, Cogen AL, et al. Commensal bacteria regulate Toll-like receptor 3-dependent inflammation after skin injury. Nat Med. 2009;15:1377-82.

32. Rennekampff HO, Hansbrough JF, Kiessig V, Dore C, Sticherling M, Schroder JM. Bioactive interleukin-8 is expressed in wounds and enhances wound healing. J Surg Res. 2000;93:41-54.

33. Iocono JA, Colleran KR, Remick DG, Gillespie BW, Ehrlich HP, Garner WL. Interleukin-8 levels and activity in delayed-healing human thermal wounds. Wound repair and regeneration : official publication of the Wound Healing Society [and] the European Tissue Repair. Society. 2000:8:216-25.

34. Grimstad O, Sandanger O, Ryan L, Otterdal K, Damaas JK, Pukstad B, et al. Cellular sources and inducers of cytokines present in acute wound fluid. Wound Repair Regen. 2011;19:337-47.

35. Gillitzer R, Goebeler M. Chemokines in cutaneous wound healing. J Leukoc Biol. 2001:69:513-21.

36. Grimstad O, Pukstad B, Stenvik J, Espevik T. Oligodeoxynucleotides inhibit Toll-like receptor 3 mediated cytotoxicity and CXCL8 release in keratinocytes. Exp Dermatol. 2012;21:7-12.

37. Kajita A, Morizane S, Takiguchi T, Yamamoto T, Yamada M, Iwatsuki K. Interferon-Gamma Enhances TLR3 Expression and Anti-Viral Activity in Keratinocytes. J Invest Dermatol. 2015;135:2005-11.

38. Olaru F, Jensen LE. Chemokine expression by human keratinocyte cell lines after activation of Toll-like receptors. Exp Dermatol. 2010;19:e314-6.

39. Gyulai R, Hunyadi J, Kenderessy-Szabo A, Kemeny L, Dobozy A. Chemotaxis of freshly separated and cultured human keratinocytes. Clin Exp Dermatol. 1994;19:309-11.

40. Jiang WG, Sanders AJ, Ruge F, Harding KG. Influence of interleukin-8 (IL-8) and IL-8 receptors on the migration of human keratinocytes, the role of PLC-gamma and potential clinical implications. Exp Ther Med. 2012:3:231-6.

41. Devalaraja RM, Nanney LB, Du J, Qian Q, Yu Y, Devalaraja MN, et al. Delayed wound healing in CXCR2 knockout mice. J Invest Dermatol. 2000;115:234-44.

42. Milatovic S, Nanney LB, Yu Y, White JR, Richmond A. Impaired healing of nitrogen mustard wounds in CXCR2 null mice. Wound Repair Regen. 2003; 11:213-9.

43. Kroeze KL, Boink MA, Sampat-Sardjoepersad SC, Waaijman T, Scheper RJ, Gibbs S. Autocrine regulation of re-epithelialization after wounding by chemokine receptors CCR1, CCR10, CXCR1, CXCR2, and CXCR3. J Invest Dermatol. 2012;132:216-25.

44. Grada A Otero-Vinas M, Prieto-Castrillo F, Obagi Z, Falanga V. Research Techniques Made Simple: Analysis of Collective Cell Migration Using the Wound Healing Assay. J Invest Dermatol. 2017:137:e11-6.

45. Tredget EB, Demare J, Chandran G, Tredget EE, Yang L, Ghahary A. Transforming growth factor-beta and its effect on reepithelialization of partial-thickness ear wounds in transgenic mice. Wound Repair Regen. 2005;13:61-7.

46. Sidhu GS, Thaloor D, Singh AK, Raghunath PN, Maheshwari RK. Enhanced biosynthesis of extracellular matrix proteins and TGF-beta 1 by polyinosinicpolycytidylic acid during cutaneous wound healing in vivo. J Cell Physiol. 1996;169:108-14.

47. Zhan Q, Song R, Zeng Q, Yao Q, Ao L, Xu D, et al. Activation of TLR3 induces osteogenic responses in human aortic valve interstitial cells through the NF-kappaB and ERK1/2 pathways. Int J Biol Sci. 2015;11:482-93.

48. Valluru M, Staton CA, Reed MW, Brown NJ. Transforming Growth Factorbeta and Endoglin Signaling Orchestrate Wound Healing. Front Physiol. $2011 ; 2: 89$

49. Lamouille $S, X u$ J. Derynck R. Molecular mechanisms of epithelialmesenchymal transition. Nat Rev Mol Cell Biol. 2014;15:178-96. 
50. Nieto MA, Cano A. The epithelial-mesenchymal transition under control: global programs to regulate epithelial plasticity. Semin Cancer Biol. 2012;22:361-8.

51. Harada K, Sato Y, Ikeda H, Isse K, Ozaki S, Enomae M, et al. Epithelialmesenchymal transition induced by biliary innate immunity contributes to the sclerosing cholangiopathy of biliary atresia. J Pathol. 2009;217:654-64.

52. Rørth P. Collective cell migration. Annu Rev Cell Dev Biol. 2009;25:407-29.

53. Vasiliev JM. Reorganization of molecular morphology of epitheliocytes and connective-tissue cells in morphogenesis and carcinogenesis. Biochemistry (Mosc). 2008;73(5):528-31.

54. Palena C, Hamilton DH, Fernando RI. Influence of IL-8 on the epithelialmesenchymal transition and the tumor microenvironment. Future Oncol. 2012;8:713-22.

55. Gonzalez-Reyes S, Marin L, Gonzalez L, Gonzalez LO, del Casar JM, Lamelas ML, et al. Study of TLR3, TLR4 and TLR9 in breast carcinomas and their association with metastasis. BMC Cancer. 2010;10:665.

56. Turley EA, Veiseh M, Radisky DC, Bissell MJ. Mechanisms of disease: epithelial-mesenchymal transition-does cellular plasticity fuel neoplastic progression? Nat Clin Pract Oncol. 2008;5:280-90.

57. Umbreit C, Flanjak J, Weiss C, Erben P, Aderhold C, Faber A, et al. Incomplete epithelial-mesenchymal transition in p16-positive squamous cell carcinoma cells correlates with $\beta$-catenin expression. Anticancer Res. 2014; 34(12):7061-9.

58. Vitorino P, Meyer T. Modular control of endothelial sheet migration. Genes Dev. 2008;22:3268-81.

\section{Submit your next manuscript to BioMed Central and we will help you at every step:}

- We accept pre-submission inquiries

- Our selector tool helps you to find the most relevant journal

- We provide round the clock customer support

- Convenient online submission

- Thorough peer review

- Inclusion in PubMed and all major indexing services

- Maximum visibility for your research

Submit your manuscript at www.biomedcentral.com/submit 